\title{
THE STUDYLOAD OF THE CUTTERSOF DRILL BITS
}

• · яльченков, . • олгушин, . . улябин, . • узнецов, . · речин V. A. Pyalchenkov, V. V. Dolgushin, G. A. Kulyabin, V. G. Kuznetsov, E. G. Grechin

юменский индустри льный университет, г. юмень

лючевые слов : бурение; долото; ш рошк ; вооружение; опор ; н грузк

Key words: drilling; bit; cutter arms; a support; a load

дежность и долговечность бурового оборудов ния и инструмент з висит от многих ф кторов $[1,2]$. дним из в жнейших является величин усилий, действующих н p бочие элементы. ля буровых долот т кими элемент ми являются зубки ш рошек, непосредственно воздействующие н $\mathrm{p}$ зруш емую породу. сследов ниям 3 кономерностей вз имодействия вооружения ш рошечных долот с з боем посвящено зн чительное число к к н литических, т к и эксперимент льных р бот $[3,4,5]$. ерспективным, н н ш взгляд, для прямого эксперимент льного измерения усилий, действующих н элементы вооружения ш рошечных долот, является метод дифференци ции з боя [6]. сследов ние з ключ ется во вр щении долот под н грузкой по мет ллическому з бою, з крепленному н измерительном устройстве. озд ние осевой н грузки и вр щение долот осуществляются с помощью специ льного стенд [3]. тенд позволяет проводить испыт ния долот р зличных типор змеров, изменять осевую н грузку н долото от 0 до $200 \mathrm{k}$ и угловую скорость долот от 0,16 до $11,34 \mathrm{c}^{-1}$, что соответствует ре льным условиям роторного бурения. бой сост влен из концентрических колец. ля р здельной регистр ции усилий, действующих н венцы к ждой ш рошки, з бой р зделен н дв сектор : p бочий (измерительный) сектор I и нер бочий сектор II (рис. 1). ри вр щении долот по з бою ш рошки последов тельно конт ктируют с кольцевыми вст вк ми р бочего сектор 3 боя I.

ис. 1. ринципи льн ясхем змер и регистр ции усилий, действующихн зубья и рошек: 1, 2, 3 -кольцевой $з$ бой р бочего сектор ;

4, 5, 6, 7-тензометрические

б лки; 7, 8, 9 -вкл дыши; 10 - усилитель;

11, 12 - осииллогр фы; 16, 17 - преобр зуюш, я пn $p$ тур ; $X_{1}, X_{2}, X_{3}$ - ось ш рошки
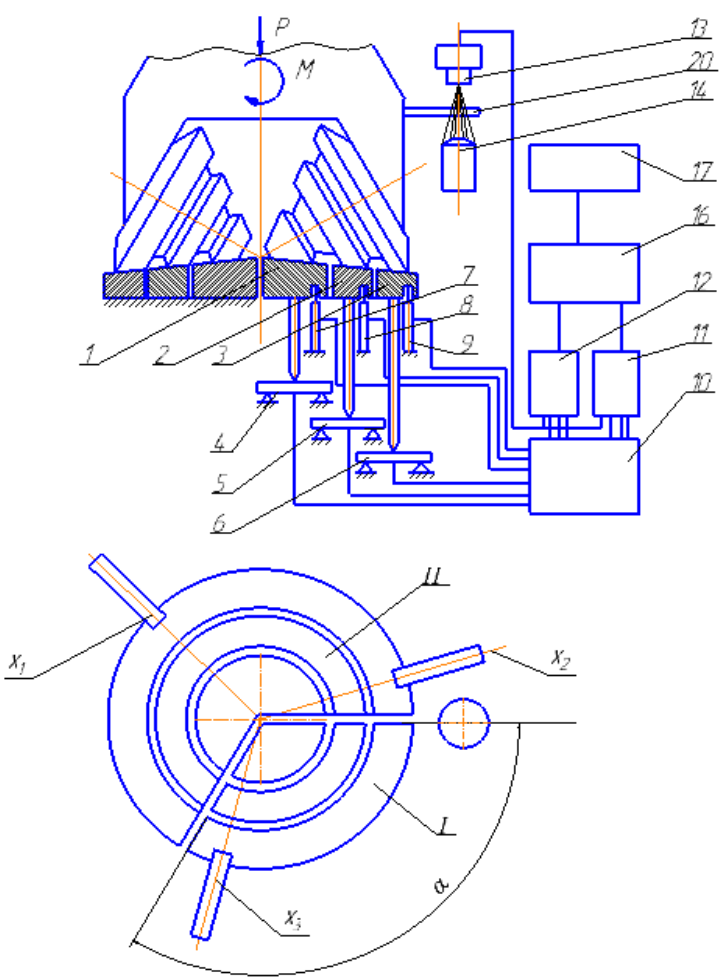
гол р бочего сектор выбир ется т к, чтобы в р бочем секторе одновременно могл н ходиться только одн ш рошк долот . ст льные ш рошки долот в д нный момент времени н ходятся в нер бочем секторе з боя II, неподвижно з крепленном н корпусе измерительного устройств . ждый венец ш рошки опир ется н свой кольцевой уч сток 1, 2, 3 р бочего сектор . ертик льные сост вляющие ре кций вз имодействия зубьев ш рошки с з боем, п р ллельные оси вр щения долот, деформируют тензометрические 6 лки 4, 5, 6. увствительными элемент ми для регистр ции т нгенци льных сост вляющих ре кций вз имодействия зубьев ш рошки с з боем, н пр вленных перпендикулярно оси вр щения долот , служ т специ льные вкл дыши 7, 8, 9, консольно з крепленные в корпусе измерительного устройств . еформ ции 6 лок и упругих вкл дышей преобр зуются тензометрическими д тчик ми в электрические сигн лы, пропорцион льные величин м осевых и т нгенци льных ре кций вз имодействия зубков ш рошек долот с з боем, которые регистрируются и обр б тыв ются с помощью специ льной пп р туры. рис. 2 приведен пример осциллогр ммы, н которой з пис ны осевые усилия, действующие н р зличные венцы ш рошек.

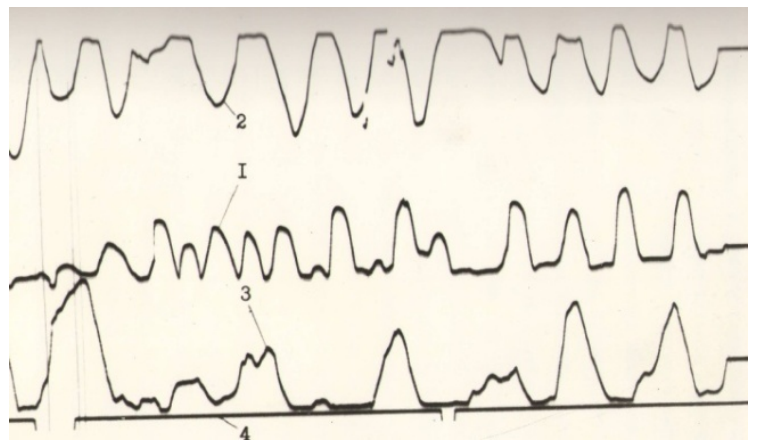

ис. 2. сциллогр мм изменения осевых сост вляющих усилий:

1 -усилиен периферийном венце; 2 -усилиен среднем венце; 3 -усилиен вершинном венце; 4 - линия р згр ничения уч стков отдельных ш рошек

сновной объем исследов ний выполнен н долот х 215,9 - , предн зн ченных для бурения в крепких пород х с очисткой з боя сж тым воздухом или воздушно-водяной смесью. опуск ем я предельн я осев я н грузк н долото сост вляет $250 \mathrm{~K}$, рекомендуемые угловые скорости долот - от 0,8 до $1,2 \mathrm{c}^{-1}$. ыбор д нного тип долот в к честве основного объект исследов ния обусловлен тем, что вооружение ш рошек этого долот изготовлено из твердоспл вных зубков одного тип

26 с полусферической головкой, что позволяет при исследов ниях исключ ть возможное влияние формы зубков н исследуемые п р метры. роме того, опорные узлы ш рошек этих долот выполнены по широко р спростр ненной схеме: большой роликовый подшипник - ш риковый $з$ мковый подшипник - м лый роликовый подшипник. то позволяет р спростр нить результ ты исследов ний д нных долот н долот других типов, имеющих т кую же схему опорных узлов. рис. 3 приведены схемы вооружения ш рошек исследуемых долот и дифференци ции з боя по венц м.

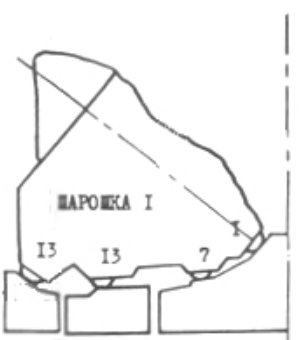

ис. 3. хем вооружения и рошекдолот дифференци ции з боя повенц м

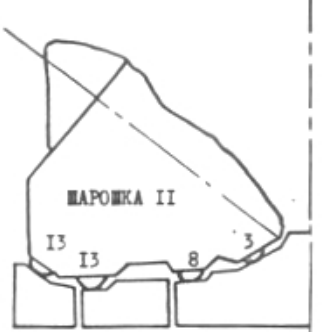

еФть иг 3

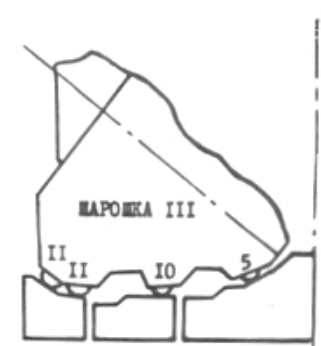

215,9 - и схем 
сследов ния проводились н мет ллическом з бое, изготовленном из м лоуглеродистой конструкционной ст ли. кономерности р спределения усилий по элемент м вооружения, полученные при исследов ниях н мет ллическом з бое, будут, н н ш взгляд, сохр няться и при бурении в крепких и очень крепких горных пород х. то подтвержд ется ср внением результ тов н литических и эксперимент льных исследов ний $[3,7,8]$ с результ т ми, полученными н ми при исследов нии отр бот нных долот в промышленных условиях [9]. целью сокр щения времени прир ботки долот мет ллический з бой изготовлялся с профилем, воспроизводящим профиль прир бот нного з боя. еред н ч лом з писи долото прир б тыв лось к 3 бою в течение 10-20 оборотов долот при осевой н грузке $80 \mathrm{k}$ и угловой скорости долот $1,31 \mathrm{c}^{-1}$ до обр зов ния н 3 бое лунок глубиной 1-2 мм. кой режим прир ботки обеспечив ет конт кт с з боем зубков всех ш рошек и исключ ет возможность конт кт с з боем корпусов ш рошек. сев я н грузк н долото при проведении исследов ний не превыш л $160 \mathrm{k}$. стот вр щения долот выбир л сь в 3 висимости от цели проводимого исследов ния и н ходил сь в предел $\mathrm{x}$ от 0,16 до $11,34 \mathrm{c}^{-1}$.

езульт ты исследов ний р спределения осевой н грузки по венц м к ждой ш рошки долот 215,9 - позволяют сдел ть вывод о том, что средняя з груженность венцов р зличных ш рошек зн чительно отлич ется друг от друг (т блиц ). ибольш я доля всей осевой н грузки, действуюшей н долото приходится н средний венец первой ш рошки. тносительн я з груженность этого венц при н грузке н долото $80 \mathrm{k}$ и угловой скорости долот $3,3 \mathrm{c}^{-1}$ сост вляет $19,1 \%$ от общей осевой н грузки н долото. то зн чительно превосходит относительную з груженность соседних с ним периферийного и вершинного венцов, восприним ющих соответственно 10,6 и 13,4 \% всей осевой н грузки н долото.

н логичн я к ртин н блюд ется и для других ш рошек исследуемого долот (см. т блицу).

\begin{tabular}{|l|c|c|c|c|c|c|c|c|c|}
\hline \multirow{2}{*}{ ок з тель з груженности венц } & \multicolumn{9}{|c|}{ орядковый номер венц } \\
\cline { 2 - 10 } & 1 & 2 & 3 & 4 & 5 & 6 & 7 & 8 & 9 \\
\hline реднее зн чение усилия, к & 9,9 & 18,1 & 12,5 & 8,3 & 11,3 & 8,8 & 10,0 & 5,2 & 5,4 \\
\hline реднее зн чение усилия, \% & 10,6 & 19,1 & 13,4 & 8,7 & 12,2 & 9,5 & 10,8 & 9,9 & 5,8 \\
\hline редний м ксимум усилия, к & 13,6 & 25,0 & 21,2 & 12,6 & 16,0 & 14,8 & 12,7 & 16,6 & 8,7 \\
\hline редний минимум усилия, к & 6,4 & 10,8 & 3,5 & 4,1 & 6,4 & 2,6 & 7,5 & 3,8 & 1,8 \\
\hline мплитуд усилия, к & 7,2 & 14,2 & 17,7 & 8,5 & 9,6 & 12,2 & 5,2 & 12,8 & 6,9 \\
\hline
\end{tabular}

ля удобств все венцы ш рошек пронумеров ны по порядку от периферийного венц первой ш рошки (венец 1) до вершинного венц третьей ш рошки (венец 9). уммиров в относительные н грузки, действующие н венцы одной ш рошки, можно уст новить, что н иболее н груженной является перв я ш рошк, восприним ющ я $43,1 \%$ общей н грузки н долото, второе место по уровню 3 груженности 3 ним ет втор я ш рошк $(30,4 \%)$, и н именее н груженной является третья ш рошк $(26,5 \%)$.

ксперимент льные исследов ния силового вз имодействия вооружения долот

215, 9 - с мет ллическим з боем пок з ли высокую степень достоверности и сходимости результ тов, получ емых при переходе от опыт к опыту, что говорит о пр вильности выбр нной методики и ее н дежности. о результ т м исследов ния был предложен и ре лизов н способ уменьшения нер вномерности р спределения осевой н грузки по элемент м вооружения долот $[10,11,12]$. зр бот нн я методик позволяет весьм быстро получ ть большой объем информ ции о з грузке всех элементов долот и может использов ться для оптимиз ции конструкции, к к вооружения, т к и опорных узлов ш рошечных долот.

писок литер туры

1. етоды обеспечения н дежности эксплу т шии скв жинного оборудов ния / . . у учумов, . . яльченков, . . яльченков. - юмень: юм, 2005. - 148 с

2. рг низ ция ремонтных р бот н скв жин х в осложненных условиях р зр ботки нефтяных месторождений /. . учумов, . . яльченков, . . учумов. - юмень: юм , 2004. - 155 с.

3. яльченков . . овышение $\mathrm{p}$ ботоспособности ш рошечных долот путем $\mathrm{p}$ цион льного $\mathrm{p}$ спределения н грузок по элемент м вооружения: диссерт ция н соиск ние ученой степени к ндид т технических н ук / оссийский госуд рственный университет нефти и г з имени . . . убкин .- оскв , 1983.-216 с. 
4. олгушин . . звитие методологии моделиров ния процессов технологии бурения и скв жинных мех низмов: втореф. дис.... докт. техн. н ук. - юмень, 2008. - 260 с.

5. яльченков . . овышение р ботоспособности ш рошечных долот путем р цион льного р спределения н грузок по элемент м вооружения: втореф. дис.... к нд. техн. н ук. - оскв , 1983. - 23 с.

6. стройство для исследов ния ш рошечного долот ; .c. $840268 \quad$ : $219 / 08 /$. . иногр дов, оротков, . . шков, . . р гин, . . яльченков. - № 2729036/22-03; з явл.23.02.79; опубл.23.06.81, юл. № 23. -4 с.: черт.

7. яльченков . . лияние жесткости опорного узл н з груженность венцов ш рошек долот // унд мент льные исследов ния. - 2016. - № 5-3. - . 502-506 [ лектронный pecypc]. - ежим доступ : http://fundamentalresearch.ru/ru/article/view?id=40330 (д т обр щения: 18.07.2016).

8. яльченков . . оделиров ние з груженности подшипников опоры ш рошечного долот // ex ник и процессы упр вления: м тери лы сероссийской н учно-пр ктической конференции. - юмень: юм , 2015. - . 105-109.

9. яльченков . . ритерии р ботоспособности вооружения буровых ш рошечных долот // звестия вузов. ефть и г 3. - 2016. - № 1. - . 110-116.

10. яльченков . . пособ уменьшения нер вномерности р спределения осевой н грузки по вооружению ш рошечных долот // унд мент льные исследов ния. - 2015. - № 12-5. - . 945-949 [ лектронный ресурс]. - ежим доступ : http://fundamental-research.ru/ru/article/view?id=39656 (д т обр щения: 13.01.2016).

11. яльченков . . спыт ния ш рошечного долот с уменьшенной нер вномерностью р спределения осевой н грузки по элемент м вооружения // унд мент льные исследов ния. - 2016. - № 1-1. - . 48-52; [ лектронный pecypc]. - ежим доступ : http://fundamental-research.ru/ru/article/view?id=39791 (д т обр щения: 12.02.2016).

12. уровое ш рошечное долото; .c.1461855 : $21 \quad 10 / 16 /$. . p гин, . . одн рчук,

яльченков, . . с нов, . . уков. - № 4213595/23-03; з явл. 20.03.87; опубл. 28.02.89, юл. № 8. - 2 с.: черт.

\section{ведения об втор $x$}

яльченков л димир лексеевич, к. доцент к федры « рикл дн ямех ник», юменский индустри льный университет, г. юмень, mел.8(3452)283354,e-mail: pial228@rambler.ru

олгуиин л димир ени минович, д. профессор к федры « $т$ нки и инструменты», юменский индустри льный университет 2. юмень, тел. 8(3452)283671, e-mail: dolgushinvv@tyuiu.ru

улябин енн дий ндреевич, д. т. н., профессор к федры бурения нефтяных и г зовых скв жин, юменский индустри льный университет, г. юмень, тел. 8(3452)390363

узнецов л димир ригорвевич, д. профессор к федры бурения нефтяных и г зовых скв жин, юменский индустри льный университет, г. юмень, тел. 8(3452)390363

речин вгений лебович, д. $\kappa$ федры «рикл дня мех ник», юменскии индустри льный университет, г. юмень, тел. 8(3452)283378

\section{Information about the authors}

Pyalchenkov V. A., Candidate of Science in Engineering, associate professor of the chair «Applied mechanics», Tyumen Industrial University, phone: 8(3452)283354,e-mail: pial228@rambler.ru

Dolgushin V. V., Doctor of Engineering, director of Institute of Engineering, Industrial University of Tyumen, phone: 8(3452)283671, e-mail: dolgushinvv@tyuiu.ru

Kulyabin G. A., Doctor of Engineering, professor of the chair «Drilling of oil and gas wells», Industrial University of Tyumen, phone: 8(3452)390363

Kuznetsov V. G., Doctor of Engineering, professor of the chair "Drilling of oil and gas wells», Indus trial University of Tyumen, phone: 8(3452)390363

Grechin E. G., Doctor of Engineering, professor of the chair "Applied mechanics», Industrial University of Tyumen, phone: 8(3452)283378 